Jurnal Kimia Sains dan Aplikasi 21 (1) (2018):29-33
ISSN: 1410-8917
Jurnal Kimia
e-ISSN: 2597-9914 \&

\title{
Decolorization of Artificial Waste Remazol Black B using Electrogenerated Reactive Spesies
}

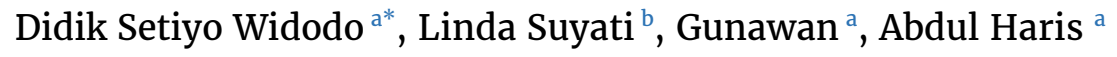 \\ a Chemistry Department, Faculty of Sciences and Mathematics, Diponegoro University, Jalan Prof. Soedarto, Tembalang, Semarang \\ * Corresponding author: widodo.ds@live.undip.ac.id
}

\begin{tabular}{|c|c|}
\hline Article Info & Abstract \\
\hline $\begin{array}{l}\text { Keywords: } \\
\text { Electrolysis, } \\
\text { decolorization, } \\
\text { remazol black B } \\
\text { (reactive black 5), } \\
\text { electrogenerated } \\
\text { reactive species }\end{array}$ & $\begin{array}{l}\text { Electrolysis method (electrodecolorization) coupled with }{ }^{\circ} \mathrm{OH} \text { radicals and chlorine } \\
\text { generation has been performed in decolorizing of artificial waste of remazol black } \mathrm{B} \\
\text { (reactive black } 5 \text { ). The electrodecolorization as one of advanced oxidation process (AOP) } \\
\text { shows its determinant potential in overcoming environmental problems due to dye } \\
\text { contained waste as well as its green in desaign and efficiency. The project aim was to } \\
\text { decolorize the RBB solution completely and effectively. The mission was completed by } \\
\text { designing decolorizing reactor working with electrolytic system in tandem with } \\
\text { electrogeneration of reactive species from } \mathrm{HCl} \text { and NaCl electrolyte. Lead oxide, } \mathrm{PbO}_{2} \\
\text { was choosen as anode. The efficiency of decolorization process was comparated with } \\
\text { those of } \mathrm{Na}_{2} \mathrm{SO}_{4} \text { as electrolyte. Data of UV-Vis spectrometry, atomic absorption } \\
\text { spectrophotometry and COD showed that the performance of electrolysis design was } \\
\text { significantly enhanced with the reactive species generation process. Electrolysis of } 100 \\
\text { mL sample of } 200 \mathrm{mgL}^{-1} \mathrm{RBB}_{\text {ath }} \text { witheactive species generation was rearched almost two- } \\
\text { fold faster in decolorizing the dye solution rather than in } \mathrm{Na}_{2} \mathrm{SO}_{4} \text { one. The design rearchs } \\
\text { more than } 99 \% \text { in decoloriziation percentages, reducing COD more than } 96 \% \text { indicating } \\
\text { the potential and effectiveness of electroremediation process. }\end{array}$ \\
\hline
\end{tabular}

Abstrak

Kata Kunci:

Elektrolisis, dekolorisasi, remazol black B (reactive black 5), spesies reaktif elektroregenerasi

Metode elektrolisis (elektrodecolorization) ditambah dengan $\mathrm{OH}$ radikal dan penghasilan klorin telah dilakukan dalam dekolorisasi limbah buatan remazol black B (reaktif hitam 5). Elektrodekolorisasi sebagai salah satu proses oksidasi lanjut menunjukkan potensi besarnya dalam mengatasi masalah lingkungan karena pewarna yang terkandung limbah dan di sisi lain, ramah dalam desain dan dan efisien. Tujuan proyek adalah untuk mendekolorisasi larutan RBB secara sempurna dan efektif. Misi ini diselesaikan dengan merancang reaktor dekolorisasi yang bekerja dengan sistem elektrolitik bersama-sama dengan elektrogenerasi spesies reaktif dari $\mathrm{HCl}$ dan elektrolit $\mathrm{NaCl}$. Timbal oksida, $\mathrm{PbO}_{2}$ dipilih sebagai anoda. Efisiensi proses dekolorisasi ini dibandingkan dengan $\mathrm{Na}_{2} \mathrm{SO}_{4}$ sebagai elektrolit. Data spektrometri UV-Vis, spektrofotometri serapan atom dan COD menunjukkan bahwa kinerja desain elektrolisis secara signifikan ditingkatkan dengan adanya proses pembentukan spesies reaktif. Elektrolisis $100 \mathrm{~mL}$ sampel $200 \mathrm{mgL}^{-1} \mathrm{RBB}$ dengan generasi spesies reaktif menunjukkan hampir dua kali lipat lebih cepat dibandingkan dengan mendekolorisasi larutan pewarna menggunakan $\mathrm{Na}_{2} \mathrm{SO}_{4}$. Desain ini menghasilkan lebih dari 99\% dekolorisasi, mengurangi COD lebih dari $96 \%$. Hal ini menunjukkan potensi dan efektivitas proses electroremediation. 


\section{Pendahuluan}

Masalah limbah cair industri batik dan tekstil tetap menjadi fokus kajian penanganan. Limbah cair batik dan tekstil selalu mengandung komponen polutan zat warna baik yang biodegradable maupun recalcitrant. Sifat tersebut berkait dengan jenis golongan senyawaan atau gugus fungsi yang terdapat dalam struktur zat warna. Di sisi lain, produksi batik dan tekstil yang terus meningkat berdampak pada jumlah buangan yang semakin tak terkendali [1].

Penggunaan pewarna sintetik seperti senyawan azo-remazol black $B$ (reactive black 5 ), basic red 76, acid red 33-mendominasi pemilihan pewarna sintetik, karena dalam aplikasi pewarnaan menghasilkan warna yang intensif dengan proses yang mudah dan sangat larut dalam air. Remazol black B (RBB) sebagai salah satu pewarna sintetik jenis azo yang banyak dipilih memerlukan kajian penanganan, sehingga limbah yang mengandung RBB dapat dikelola dengan baik, efektif dan efisien.

Berbagai metode telah diusulkan untuk mematangkan sistem desain yang efektif dan efisien. Penanganan limbah cair yang mengandung zat warna telah sejak berabad dikaji untuk menurunkan atau merusak struktur zat warna sehingga tidak lagi membahayakan lingkungan. Pendekatan redoks merupakan salah satu cara yang banyak dikaji, disamping adsorpsi, koagulasi, flokulasi, lumpur aktif, biologi, mikrobiologi dan pengendapan. Pendekatan redoks antara lain metode Fenton, fotokatalisis, elektrofotokatalisis, dan elektrolisis. Pendekatan ini tercakup dalam konteks yang lebih tajam adalah sistem elektrokimia. Pemikiran-pemikiran pendekatan elektrokimia telah banyak dikaji. Salah satu pendekatan elektrokimia adalah metode elektrolisis [2, 3].

Pendekatan elektrolisis merupakan metode alternatif dalam penanganan limbah yang mengandung zat warna, sebagaimana telah dilakukan oleh peneliti terdahulu [4-7]. Keberhasilan teknik elektrolisis mensyaratkan desain sel elektrolisis yang efisien mencakup variabel elektroda, elektrolit, $\mathrm{pH}$ sampel, dan utilisasi energi yang memadahi. Sementara, mempertimbangkan sistem degradasi sampel dengan metode Fenton [8, 9] menunjukkan bahwa kesuksesan desain Fenton terletak pada sistem degradasi yang melibatkan radikal hidroksil, $\bullet \mathrm{OH}$. Radikal ini sangat potensial merusak sistem struktur senyawa organik karena struktur elektron radikal yang sangat tidak stabil. Pada metode berbeda, pembentukan radikal $\bullet \mathrm{OH}$ dalam degradasi struktur senyawaan organik dapat ditempuh dengan penggunaan material $\mathrm{PbO}_{2}$. Pada berbagai kajian modifikasi elektroda untuk eletrolisis juga memanfaatkan $\mathrm{PbO}_{2}$ untuk meningkatkan efektivitas metode, meskipun sangat sulit pada tataran preparasi elektroda. Fakta ini memunculkan pemikiran untuk menyederhanakan sistem pembangkitan radikal serupa untuk menghasilkan proses yang efisien.

Elektrolit sebagai media reaktor pengolahan limbah juga memegang fungsi penting dalam memperoleh efektivitas proses. Elektrolit memerankan fungsi distribusi dan penghantaran listrik untuk proses penanganan limbah. Pengaruh elektrolit telah dilaporkan pada penenlitian terdahulu [10] dengan penggunaan elektrolit $\mathrm{NaCl}, \mathrm{NaNO}_{3}$ dan $\mathrm{Na}_{2} \mathrm{SO}_{4}$ pada degradasi zat warna sintetik. Thiam $d k k$. [11] melakukan hal yang analog untuk pemrosesan pewarna ponceau $4 R$. Efektivitas proses sebagaimana telah dikaji oleh peneliti terdahulu memungkinkan melanjutkan kajian ini dengan memodifikasi metode. Penelitian ini difokuskan pada sistem pembangkitan radikal dengan mengutamakan proses ramah lingkungan, cepat dan efisien.

\section{Metode Penelitian}

\section{Alat dan Bahan}

Bahan yang digunakan meliputi: zat warna remazol black B (RBB, reactive black 5, dye content $\geq 50 \%$ dari Sigma-Aldrich), $\mathrm{NaCl}$ (p.a., Merck), $\mathrm{Na}_{2} \mathrm{SO}_{4}$ (p.a., Merck), lempeng elektroda $\mathrm{Pb}-\mathrm{PbO}_{2}$ dan $\mathrm{Cu}-\mathrm{PbO}_{2}$, akuades.

Alat-alat yang digunakan: seperangkat peralatan gelas (Pyrex), bench power supply (GW INSTEK GPR3060D), digital multimeter (SINHWA DT9205A), Potentiostat (Core Sell CS 150), Spektrometri UV-Vis (Shimadzu), dan Spektrofotometer Serapan Atom (Shimadzu)

\section{Prosedur Penelitian}

Penelitian ini diawali preparasi larutan limbah artifisial, dan analisis awal sampel untuk memperoleh data spektra UV-Vis sampel, analisis AAS, dan nilai COD. Sampel limbah aritifisial disiapkan dengan membuat larutan RBB $200 \mathrm{mgL}^{-1}$. Sampel ini kemudian dianalisis secara sepktrometri UV-Vis untuk memperoleh spektra dan menetapkan panjang gelombang maksimum RBB pada elektrolisis. Sampel juga dianalisis secara AAS untuk memperoleh data kandungan $\mathrm{Pb}$ dan $\mathrm{Cu}$. Kandungan senyawaan organik sampel, diuji dengan analisis COD secara spektrometri.

\section{Penentuan Potensial Aplikasi}

Elektrolisis sampel artifisial dilakukan pada potensial aplikasi yang ditentukan dengan mengelektrolisis larutan RBB $200 \mathrm{mgL}^{-1}$ pada variasi potensial dari $0-10 \mathrm{~V}$ dengan elektroanalizer Bench Power Supply GW INSTEK GPR-3060D dan penggunaan elektroda $\mathrm{Pb}-\mathrm{PbO}_{2}$ dan $\mathrm{Cu}-\mathrm{PbO}_{2}$. Arus kecil yang mengalir diukur dengan multimeter SINHWA DT9205A. Data arus di-plotting sebagai grafik arus terhadap potensial. Titik belok grafik ditetapkan sebagai potensial dekomposisi, dan potensial aplikasi ditetapkan beberapa satuan potensial lebih besar dari titik belok tersebut.

\section{Penentuan Waktu Dekolorisasi Sampel sebagai Fungsi} Elektrolit

Kajian pengaruh pembangkitan spesies reaktif diimplementasikan dengan pemilihan elektrolit selama elektrodekolorisasi. Elektrolisis divariasi dengan elektrolit $\mathrm{NaCl}$ dan $\mathrm{Na}_{2} \mathrm{SO}_{4}$. Elektrolisis dilakukan pada potensial aplikasi selama beberapa jam. Setiap 30 menit, 
absorbansi larutan diukur pada panjang gelombang 595 nm. Data absorbansi dikonversi menjadi konsentrasi RBB tersisa setiap waktu. Pengaruh elektrolit dilihat dari parameter waktu yang diperlukan untuk menyelesaikan dekolorisasi hingga lebih dari $99 \%$.

\section{Elektrodekolorisasi Sampel dan Analisis}

Sampel larutan remazol black B $200 \mathrm{mgL}^{-1} 100 \mathrm{~mL}$ ditambah elektrolit $\mathrm{NaCl} 0,1 \mathrm{M}$, kemudian dielektrolisis dengan elektroda $\mathrm{Pb}-\mathrm{PbO}_{2}$ pada potensial aplikasi $5 \mathrm{~V}$. Larutan pascaelektrolisis dianalisis seperti analisis awal sampel. Prosedur yang sama juga dilakukan untuk elektrolit $\mathrm{Na}_{2} \mathrm{SO}_{4}$ dan $\mathrm{HCl}$ baik elektrolda $\mathrm{Pb}-\mathrm{PbO}_{2}$ maupun $\mathrm{Cu}-\mathrm{PbO}_{2}$. Persentase dekolorisasi dihitung dengan rumus:

$\%$ Dekolorisasi $=\left([\mathrm{RBB}]_{\mathrm{awal}}-[\mathrm{RBB}]_{\mathrm{akhir}}\right) /[\mathrm{RBB}]_{\mathrm{awal}} \mathrm{X} 100 \%$

Larutan setelah dielektrolisis dianalisis secara spektrometrik UV-Vis, AAS, COD, voltammentri siklik sederhana dan $\mathrm{pH}$. Hasil analisis menjadi dasar penilaian potensi dan efektivitas desain dekolorisasi.

\section{Hasil Dan Pembahasan}

Kajian analisis awal sebelum dekolorisasi meliputi kajian spektra UV-Vis, kandungan logam (AAS), COD, dan $\mathrm{pH}$-diperoleh data awal sebagai pembanding dengan data akhir. Sebelum proses elektrodekolorisasi, absorbansi sampel limbah artifisial remazol black B 200 $\mathrm{mgL}^{-1}$ diukur pada panjang gelombang maksimum 597 $\mathrm{nm}$, tercatat absorbansi 0,947 pada pengenceran, kandungan 10 kalinya. logam $\mathrm{Pb}$ sebesar 0,968 ppm dan $\mathrm{Cu}$ 2,443 ppm, pH 7. Berdasarkan hal tersebut pewarna tekstil mengandung mengandung logam yang ditambahkan saat sintesis dalam bentuk sebagai senyawaan aromatik sebagaimana disitir pada laporan lain [12].

Tabel 1: Hasil analisis awal dan akhir sampel remazol black B

\begin{tabular}{|c|c|c|c|c|c|c|}
\hline \multirow[b]{2}{*}{ Sampel } & \multirow{2}{*}{$\begin{array}{c}\text { Waktu } \\
\text { Elektrolisis } \\
\text { (Menit) }\end{array}$} & \multirow{2}{*}{$\begin{array}{l}\text { Persentase } \\
\text { Dekolorisasi } \\
\text { (\%) }\end{array}$} & \multicolumn{2}{|c|}{ Kadar Logam } & \multicolumn{2}{|c|}{$\mathrm{pH}$} \\
\hline & & & $\begin{array}{c}\mathrm{Pb} \\
(\mathrm{ppm})\end{array}$ & $\begin{array}{c}\mathrm{Cu} \\
(\mathrm{ppm})\end{array}$ & Awal & Akhir \\
\hline RBB 200 mg/L & - & - & 0,968 & 2,443 & 7 & - \\
\hline $\mathrm{RBB}+\mathrm{NaCl}\left(\mathrm{Pb}-\mathrm{PbO}_{2}\right)$ & 150 & 100,0 & 8,923 & 0,253 & 7 & 11 \\
\hline $\mathrm{RBB}+\mathrm{NaCl}\left(\mathrm{Cu}-\mathrm{PbO}_{2}\right)$ & 150 & 98,2 & 44,93 & 0,521 & 7 & 12 \\
\hline $\begin{array}{c}\mathrm{RBB}+\mathrm{Na}_{2} \mathrm{SO}_{4} \\
\left(\mathrm{~Pb}-\mathrm{PbO}_{2}\right)\end{array}$ & 240 & 98,5 & 13,12 & 0,596 & 7 & 5 \\
\hline $\begin{array}{l}\mathrm{RBB}+\mathrm{Na}_{2} \mathrm{SO}_{4} \\
\left(\mathrm{Cu}-\mathrm{PbO}_{2}\right)\end{array}$ & 240 & 98,5 & 7,138 & 0,419 & 7 & 7 \\
\hline
\end{tabular}

Dalam industri pewarnaan tekstil, logam tembaga merupakan logam yang paling mendominasi setiap jenis pewarna yang digunakan [8], sedangkan timbal biasa digunakan sebagai campuran pewarna, yaitu warna putih timbal sebagai $\left[\mathrm{Pb}(\mathrm{OH})_{2} .2 \mathrm{PbCO}_{3}\right]$ dan warna merah sebagai timbal merah $\left(\mathrm{Pb}_{3} \mathrm{O}_{4}\right)$. Logam-logam tersebut dapat terakumulasi pada limbah cair sesudah penggunaan pada industri tekstil atau batik.

Waktu dekolorisasi $100 \mathrm{~mL}$ sampel remazol black $B$ $200 \mathrm{mgL}^{-1}$ dalam sistem elektrolit $\mathrm{NaCl}, \mathrm{HCl}$ dan $\mathrm{Na}_{2} \mathrm{SO}_{4}$ dengan elektroda $\mathrm{Cu}-\mathrm{PbO}_{2}$ maupun $\mathrm{Pb}-\mathrm{PbO}_{2}$ berbeda bergantung elektrolit. Penyediaan ion $\mathrm{Cl}^{-}$baik sebagai $\mathrm{HCl}$ maupun $\mathrm{NaCl}$ jauh menungkatkan masa waktu dekolorisasi, 150 menit dibanding 240 menit pada sistem elektrolit $\mathrm{Na}_{2} \mathrm{SO}_{4}$. Persentase dekolorisasi juga tercatat sangat baik (Gambar 1). Dekolorisasi dalam elektrolit $\mathrm{Cl}^{-}$berlangsung lebih cepat, terkait dengan proses tandem dalam perusakan struktur zat warna. Dekolorisasi elektrolitik berlangsung melalui dua mekanisme, redoks biasa dan reaksi radikal. Pelibatan sistem spesies radikal didasarkan pada pembentuan in situ radikal $\bullet \mathrm{OH}$ dan $\mathrm{Cl}_{2}$ selama proses elektrolisis. Radikal menyerang molekul zat warna dan mendestruksi molekul menjadi molekul sederhana. Radikal terbentuk di permukaan bahan elektroda melalui inisiasi energi listrik yang dicatu dari sistem elektrolisis pada bahan $\mathrm{PbO}_{2}$. Bahan ini penyediaan permukaan yang sesuai untuk pembentukan radikal $\bullet \mathrm{OH}$ ketika berinteraksi dengan air dan $\mathrm{Cl}_{2}$ ketika dalam sistem tersedia ion $\mathrm{Cl}^{-}$[8]. Pembentukan spesies reaktif dari $\mathrm{Cl}^{-}$melibatkan tahap-tahap di bawah [13].

$\mathrm{Cl}^{-} \rightarrow \mathrm{Cl}_{2}+2 e^{-}$

Pada tahap kedua, $\mathrm{Cl}_{2}$ membetuk asam hipoklorit

$$
\mathrm{Cl}_{2}+\mathrm{H}_{2} \mathrm{O} \rightarrow \mathrm{HClO}+\mathrm{Cl}^{-}+\mathrm{H}^{+}
$$

yang berada dalam kesetimbangan dissosiasi menjadi ion hipoklorit dan hidrogen.

$$
\mathrm{HClO} \rightarrow \mathrm{ClO}^{-}+\mathrm{H}^{+}
$$

Pada tahap berikutnya, spesies-spesies ini bereaksi secara beruntun, termasuk berekasi dengan radikal $\bullet \mathrm{OH}$ yang dihasilkan pada bagian lain proses elektrodekolorisasi [14].

$$
\begin{aligned}
& 2 \mathrm{HClO}+\mathrm{OCl}^{-} \rightarrow \mathrm{ClO}_{3}^{-} \\
& \mathrm{ClO}_{2}{ }^{-}+\cdot \cdot \mathrm{OH} \rightarrow \mathrm{ClO}_{3}{ }^{-} \\
& \mathrm{ClO}_{3}{ }^{-}+\cdot \cdot \mathrm{OH} \rightarrow \mathrm{ClO}_{4}{ }^{-}+\mathrm{H}^{+}+\mathrm{e}^{-} \\
& 6 \mathrm{HClO}+3 \mathrm{H}_{2} \mathrm{O} \rightarrow 2 \mathrm{ClO}_{3}{ }^{-}+4 \mathrm{Cl}^{-}+12 \mathrm{H}^{+}+1,5 \mathrm{O}_{2}+6 \mathrm{e}^{-}
\end{aligned}
$$

Reaksi 4-7 melemahkan kekuatan oksidasi spesies aktif karena secara energetik kurang memungkinkan. Namun, spesies reaktif klorit dapat mengalami reaksi lain dengan kecukupan energi, $\mathrm{ClO}^{-}$dapat membentuk radikal lain yang sangat reaktif (persamaan 8 ).

$$
\mathrm{OCl}^{-} \rightarrow \cdot \mathrm{O}+\cdot \mathrm{Cl}
$$

Mekanisme dekolorisasi atas peran hipoklorit pada zat warna melalui pembangkitan klorin adalah:

Zat warna $+\mathrm{OCl}^{-} \rightarrow \mathrm{CO}_{2}+\mathrm{H}_{2} \mathrm{O}+\mathrm{Cl}^{-}$

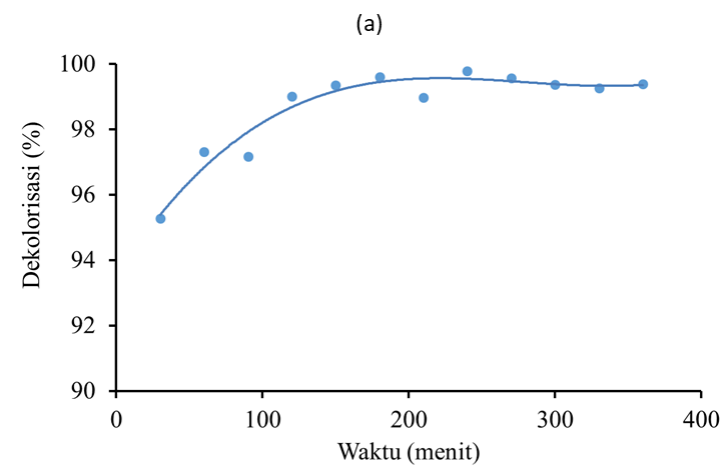


(b)

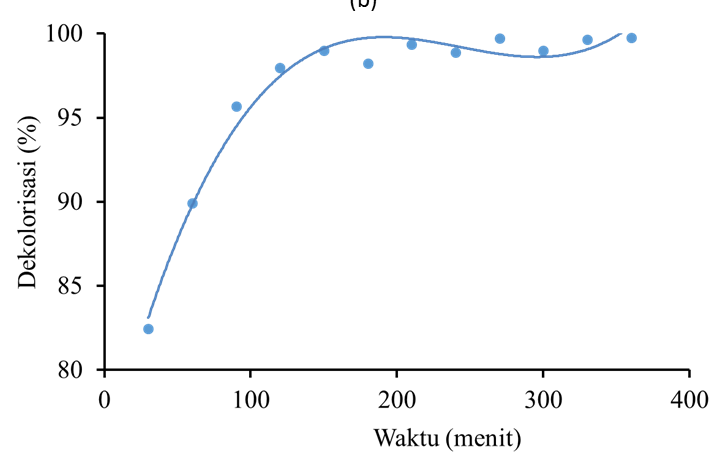

(c)

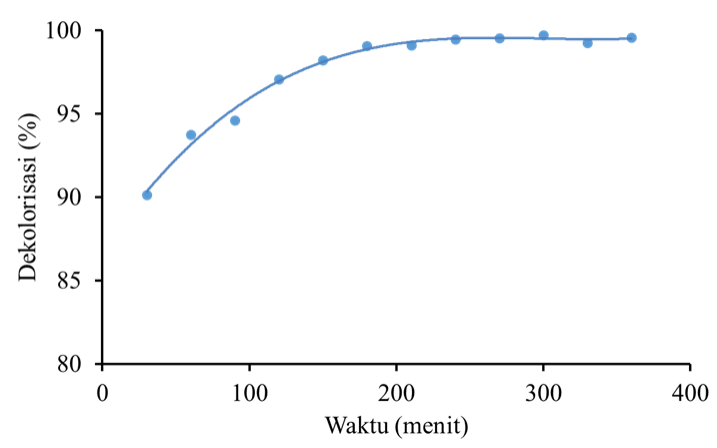

(d)

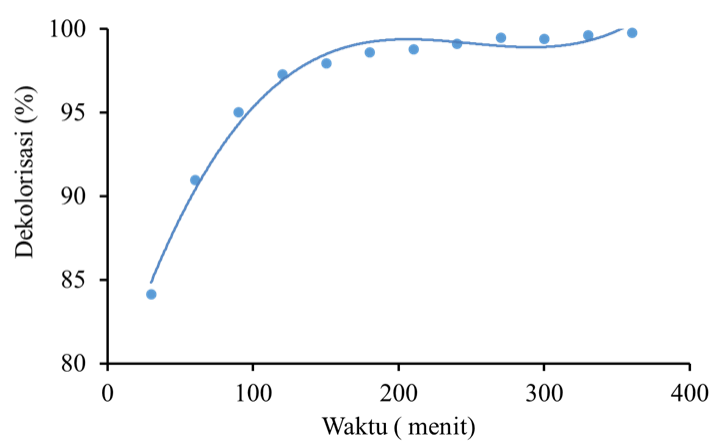

Gambar 1. Kurva hubungan antara waktu elektrolisis dan Persentase dekolorisasi sampel RBB 200 ppm dalam sistem (a) $\mathrm{NaCl}$ dengan elektroda $\mathrm{Pb}-\mathrm{PbO}_{2}$ (b) $\mathrm{NaCl}$ dengan elektroda $\mathrm{Cu}-\mathrm{PbO}_{2}$ (c) $\mathrm{Na}_{2} \mathrm{SO}_{4}$ dengan elektroda $\mathrm{Pb}-\mathrm{PbO}_{2}$ dan (d) $\mathrm{Na}_{2} \mathrm{SO}_{4}$ dengan elektroda $\mathrm{Cu}-\mathrm{PbO}_{2}$

Tabel 2: Data analisis COD

\begin{tabular}{cccc}
\hline Sampel & $\begin{array}{c}\text { COD } \\
\text { awal }\end{array}$ & $\begin{array}{c}\text { COD } \\
\text { akhir }\end{array}$ & $\begin{array}{c}\text { Penurunan } \\
(\%)\end{array}$ \\
\hline $\begin{array}{c}\text { RBB dalam } \\
\text { NaCl }\end{array}$ & 368,77 & 40,38 & 88,78 \\
\begin{tabular}{c}
$\mathrm{RBB} \mathrm{dalam}^{\mathrm{Na}_{2} \mathrm{SO}_{4}}$ \\
\hline
\end{tabular} & 251,70 & 9,01 & 96,42 \\
\hline
\end{tabular}

Pada sisi lain, penggunaan elektroda $\mathrm{PbO} 2$ menginisiasi pembentukan radikal hidroksil, $\cdot \mathrm{OH}$ untuk menyerang senyawa zat warna (remazol black B) dan menghasilkan radikal-radikal baru sehingga reaksi terjadi secara berantai dan cepat. Reaksi yang terjadi digambarkan dengan skema berikut:

$\mathrm{PbO}_{2}+\mathrm{H}_{2} \mathrm{O} \rightarrow \mathrm{PbO}_{2}[\cdot \mathrm{OH}]+\mathrm{H}^{+}+\mathrm{e}^{-}$

$\mathrm{R}+[\cdot \mathrm{OH}] \rightarrow \cdot \mathrm{R}+\mathrm{H}^{+}+\mathrm{e}^{-}$ $\cdot \mathrm{R}+\mathrm{H}^{+}+\mathrm{e}^{-} \rightarrow \mathrm{CO}_{2}+\mathrm{H}_{2} \mathrm{O}+$ mineral

$\mathrm{R}$ dalam reaksi di atas melambangkan substrat organik (zat warna).

Hasil spektra UV-Vis sampel larutan remazol black B setelah elektrolisis dapat dilihat pada Gambar 2 dan data analisis larutan remazol black B terdapat pada Tabel 1. Dari data spektra UV-Vis teramati bahwa semua larutan sampel setelah proses elektrolisis memiliki bentuk grafik yang landai atau tidak ada puncak pada panjang gelombang visible, hal ini menunjukan telah terjadinya penurunan konsentrasi zat warna, dengan perubahan warna dari biru tua menjadi bening (transparan).

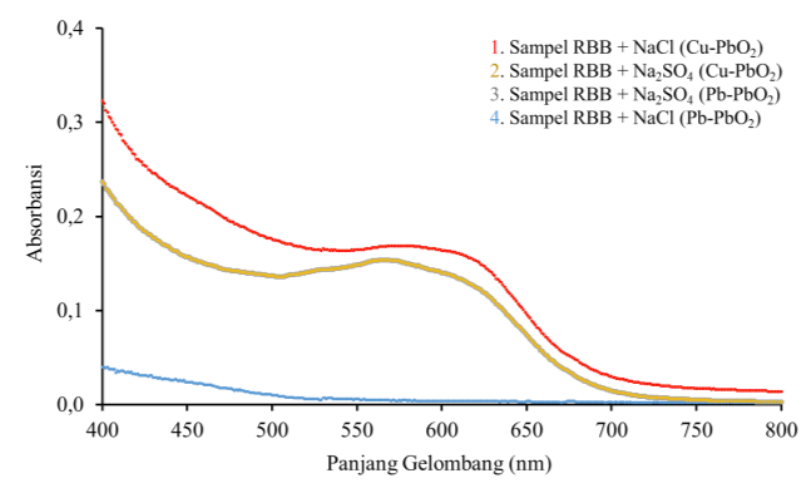

Gambar 2. Spektra UV-Vis sampel setelah proses elektrolisis

Analisis larutan setelah elektrolisis (Tabel 1) menunjukkan beberapa parameter yang harus dikaji lanjut untuk menurunkan kandungan logam dan pengaturan $\mathrm{pH}$ menuju netral. Analisis voltammetrik dengan pembandingan dengan standar $\mathrm{CO}_{2}$ terlarut juga meingindikasikan kesamaan potensail puncak yang sama dan menunjukkan keberadaan $\mathrm{CO}_{2}$ sebagai produk dekolorisasi (Gambar 3). Memperhatikan parameter COD penurunan hingga 96,42 \%, warna transparan (tak terdeteksi warna pada panjang gelombang maksimum, dekolorisasi $100 \%$ ), dan data voltammetri maka disimpulkan dekolorisasi larutan limbah artifisial yang mengandung RBB berlangsung sempurna menghasilkan $\mathrm{CO}_{2}$ dan $\mathrm{H}_{2} \mathrm{O}$. Dekolorisasi berlangsung lebih cepat pada keberadaan ion $\mathrm{Cl}^{-}$dengan pemilihan elektrolit $\mathrm{HCl}$ dan $\mathrm{NaCl}$ selama elektrolisis.

\section{Kesimpulan}

Metode elektrolisis dengan pemilihan material elektroda $\mathrm{PbO}_{2}$ dan elektrolit $\mathrm{Cl}^{-}$dan $\mathrm{Na}_{2} \mathrm{SO}_{4}$ mampu mendekolorisasi sampel limbah artifisial remozol balck $B$ (reactive blak 5) hingga sempurna. Dalam media mengandung $\mathrm{Cl}^{-}$elektrodekolorisasi berlangsung jauh lebih cepat dan penurunan COD yang cukup baik. Data riset menunjukkan elektrodekolrisasi $200 \mathrm{mgL}^{-1} \mathrm{RBB}$ sebanyak $100 \mathrm{~mL}$ dalam waktu paling singkat 150 menit mampu mencapai lebih dari $99 \%$ dekolorisasi diikuti dengan penurunan COD hingga 96,42\%. 


\section{Persantunan}

Penulis mengucapkan terimakasih atas terselesaikannya penelitian ini atas support penadaan melalui Hibah Penelitian Madya FSM Universitas Diponegoro tahun 2017 dengan nomer kontrak 1644e/UN7.5.8/PP/2017 tanggal 3 April 2017.

\section{Daftar Pustaka}

[1] Titik Darmawanti, Suhartana Suhartana, Didik Setiyo Widodo, Pengolahan Limbah Cair Industri Batik dengan Metoda Elektrokoagulasi Menggunakan Besi Bekas Sebagai Elektroda, Jurnal Kimia Sains dan Aplikasi, 13, 1, (2010) 18-24

[2] Sulistias Mustika, Abdul Haris, Nor Basid Adiwibawa Prasetya, Kajian Metode Elektrofotokatalisis, Elektrolisis dan Fotokatalisis pada Dekolorisasi Larutan Zat Warna Remazol Black B yang Mengandung Ion Logam Cu2+, Jurnal Kimia Sains dan Aplikasi, 16, 1, (2013) 17-22

[3] Arthias Cita Febriyani, Rum Hastuti, Abdul Haris, Kajian Metode Elektrofotokatalisis, Elektrolisis dan Fotokatalisis pada Dekolorisasi Larutan Zat Warna Remazol Brilliant Orange 3R yang Mengandung Ion Logam Cu2+, Jurnal Kimia Sains dan Aplikasi, 15, 1, (2012) 7-12

[4] MS Morsi, AA Al-Sarawy, WA Shehab El-Dein, Electrochemical degradation of some organic dyes by electrochemical oxidation on a $\mathrm{Pb} / \mathrm{PbO} 2$ electrode, Desalination and Water Treatment, 26, 1-3, (2011) 301-308

[5] Vinod Kumar Gupta, Rajeev Jain, Shaily Varshney, Electrochemical removal of the hazardous dye Reactofix Red 3 BFN from industrial effluents, Journal of Colloid and Interface Science, 312, 2, (2007) 292-296

http://dx.doi.org/10.1016/j.jcis.2007.03.054

[6] Haiming Zou, Yan Wang, Azo dyes wastewater treatment and simultaneous electricity generation in a novel process of electrolysis cell combined with microbial fuel cell, Bioresource Technology, 235, (2017)

167-175 http://dx.doi.org/10.1016/j.biortech.2017.03.093

[7] P D Riyanto, Elektrokimia dan aplikasinya, Graha Ilmu, Yogyakarta, 2013.

[8] Dayanne Chianca de Moura, Marco Antonio Quiroz, Djalma Ribeiro da Silva, Ricardo Salazar, Carlos Alberto Martínez-Huitle, Electrochemical degradation of Acid Blue 113 dye using TiO2nanotubes decorated with $\mathrm{PbO} 2$ as anode, Environmental Nanotechnology, Monitoring \& Management, $\quad 5, \quad$ (2016) 13-20 http://dx.doi.org/10.1016/j.enmm.2015.11.001

[9] Seong-Hoon Hong, Byung-Hyuk Kwon, Jea-Keun Lee, Il-Kyu Kim, Degradation of 2-chlorophenol by Fenton and photo-Fenton processes, Korean Journal of Chemical Engineering, 25, 1, (2008) 46-52 http://dx.doi.org/10.1007/s11814-008-0008-3

[10] GP Gallios, I Voinovschi, A Voulgaropoulos, Effect of electrolytes on the electrochemical oxidation of synthetic dyes, in: Water Treatment Technologies for the Removal of High-Toxicity Pollutants, Springer, 2009, pp. 169-176.
[11] Abdoulaye Thiam, Enric Brillas, Francesc Centellas, Pere L. Cabot, Ignasi Sirés, Electrochemical reactivity of Ponceau $4 \mathrm{R}$ (food additive E124) in different electrolytes and batch cells, Electrochimica Acta, 173, (2015) 523-533 http://dx.doi.org/10.1016/j.electacta.2015.05.085

[12] I. M. Banat, P. Nigam, G. McMullan, R. Marchant, D. Singh, The isolation of thermophilic bacterial cultures capable of textile dyes decolorization, Environment International, 23, 4, (1997) 547-551 http://dx.doi.org/10.1016/S0160-4120(97)00061-5

[13] Nasser Abu Ghalwa, Mazen Hamada, Hazem M. Abu Shawish, Omar Shubair, Electrochemical degradation of linuron in aqueous solution using $\mathrm{Pb} / \mathrm{PbO} 2$ and $\mathrm{C} / \mathrm{PbO} 2$ electrodes, Arabian Journal of Chemistry, 9, (2016) S821-S828 http://dx.doi.org/10.1016/j.arabjc.2011.08.006

[14] RB Alencar de Souza, LA Martins Ruotolo, Phenol electrooxidation in different supporting electrolytes using boron-doped diamond anodes, International Journal of Electrochemical Science, 8, 1, (2013) 643-657 